\title{
SECTION 7 OF THE CHARTER OF RIGHTS AND FREEDOMS: CONSTRAINTS ON STATE ACTION*
}

\author{
TIMOTHY J. CHRISTIAN**
}

\begin{abstract}
The following article focuses on s. 7 of the Charter, analysing the various components of the section and the drafting process which led to their making. The author reviews cases which have interpreted parts of the section as well as other cases which deal with similar legislation in other jurisdictions. He then makes suggestions as to how the section may be interpreted in the future.
\end{abstract}

\section{INTRODUCTION}

Section 7 of the Charter of Rights and Freedoms' proclaims that:

Everyone has the right to life, liberty and security of the person and the right not to be deprived thereof except in accordance with the principles of fundamental justice.

In the short history of Charter litigation, $\mathrm{s.} 7$ has already proved to be a controversial measure. Only the various subsections of $s .11$ and the ubiquitous s. 1 have attracted more judicial attention. The virtual explosion of litigation is one indication of the potential scope and impact of the provision. Further evidence may be found in the transcripts of the debates which accompanied the passage of s. 7 through the Joint Committee of the House of Commons and the Senate on the Constitution ${ }^{2}$ and the debates recorded in Hansard itself.

In this paper, I shall consider each of the components of $\mathrm{s.} 7$ and, based on the Proceedings of the Joint Committee, the cases decided to date, and certain American and European authorities, speculate as to the potential effect of the provision.

The Canadian predecessor of s. 7 is s. 1(a) of the Bill of Rights which provides: ${ }^{3}$

It is hereby recognized and declared that in Canada there have existed and shall continue to exist without discrimination by reason of race, national origin, colour, religion or sex, the following human rights and fundamental freedoms, namely, (a) the right of the individual to life, liberty, security of the person and enjoyment of property, and the right not to be deprived thereof except by due process of law.

A comparison of that provision with s. 7 of the Charter reveals two important substantive differences. First, s. 7 makes no reference to "enjoyment of property". Second, it makes no reference to "due process of law" and instead provides that there can be no deprivation of "life, liberty or security of the person" except "in accordance with the principles of fundamental justice."

The present wording of $\mathbf{s .} 7$ is identical to that which was originally proposed by the Federal government in October 1980. However, during the committee stage, two amendments which would have brought the wording of s. 7 into conformity with the Bill of Rights were proposed and

* Based on a paper presented to L.E.S.A. seminars on The Charter of Rights: One Year After, in Edmonton and Calgary, September 30 and October 1, 1983.

** Associate Dean of the Faculty of Law of the University of Alberta, Edmonton, Alberta.

1. The Canadian Charter of Rights and Freedoms, Constitution Act, 1982, Canada Gazette, Part III, Sept. 21, 1982, (en. by Canada Act, 1982 (U.K.), c. II.).

2. Special Joint Committee on the Constitution of Canada Proceedings January 26, 1981, 45:36.

3. The Canadian Bill of Rights, 1960, R.S.C., 1970, App. III. 
rejected. A brief consideration of this aspect of the Charter's evolution is essential as a background to a review of the definitional difficulties which are now faced by the courts.

\section{ENJOYMENT OF PROPERTY}

The Progressive Conservative Party proposed that s. 7 be amended to include the phrase "and enjoyment of property" immediately following the phrase "security of the person". The amendment was opposed by the N.D.P. on the ground that the provision would render the provinces incapable of effectively legislating with respect to property and would adversely affect such endeavours as the control of non-resident ownership of land by Prince Edward Island, ${ }^{4}$ the expropriation of land by Provincial governments, public ownership of national oil companies by the Federal government, the public ownership of potash mines by the Saskatchewan government, and the public ownership of asbestos corporations by the Quebec government. ${ }^{5}$

While the Liberal Party initially indicated that it would support the Conservative amendment, ${ }^{6}$ it later changed its position. The Minister of Justice defended the decision to reject the amendment on the ground that there was substantial provincial opposition to the measure because it ${ }^{7}$

... would put in jeopardy all the laws on zoning, the utilization of the land and what not, and ... [would] create in that part of the economic and social activity of every province an uncertainty that they did not want to have at all....

On January 27, 1982, the Conservative amendment was lost in Committee. A similar fate befell an identical amendment placed by the Conservatives before the House of Commons on April 23, 1981. The result is that the majority of members of the Joint Committee and the House of Commons have considered and rejected the arguments for inclusion of an express right to enjoyment of property in the Charter. More recently, the Liberal government has announced that it will seek an amendment of the Constitution to insert the right to property. In the face of this political history, is it likely that the judiciary will now construe s. 7 as protecting property rights? Does the decision to omit the right to "enjoyment of property" now preclude the courts from finding that the same right is implicit in other provisions of the Charter? These questions will be addressed infra in the section dealing with "security of the person".

\section{DUE PROCESS OF LAW}

During the committee stage, the N.D.P. proposed that $\mathrm{s} .7$ be amended by adding the phrase "including the principles of due process of law" after the phrase "in accordance with the principles of fundamental

4. On January 6, 1981, the Premier of Prince Edward Island, Angus MacLean, sent a telegram to the Joint Committee and stated the "great concern" of the Province with the proposed amendment "which adds the phrase 'enjoyment of property' to s. 2, Fundamental Rights and s. 7, Legal Rights."

5. Special Joint Committee on the Constitution of Canada Proccedings January 26, 1981, 45:36.

6. The undertaking was given by the Honourable Robert P. Kaplan, Special Joint Committee on the Constitution of Canada Proceedings January 27, 1981, 46:28.

7. Id. at January $26,1981,45: 12$. 
justice". The object of the proposed amendment was to clarify and expand the meaning of "fundamental justice" by incorporating the existing jurisprudence on the concept of due process. In the debate preceeding rejection of the amendment, several important points were made by the Minister of Justice, the Honourable Jean Chretien, and the Assistant Deputy Minister responsible for drafting portions of the Charter, Dr. B.L. Strayer Q.C. In response to the question whether the concept of "fundamental justice" was intended to include the concept of "due process' as found in s. 1 of the Canadian Bill of Rights, ${ }^{8}$ Dr. Strayer said: ${ }^{9}$
... it was our belief that the words "fundamental justice" would cover the same thing as what is called procedural due process, that is the meaning of due process in relation to requiring fair procedure. However, it in our view does not cover the concept of what is called substantive due process, which would impose substantive requirements as to the policy of the law in question. This has been most clearly demonstrated in the United States in the area of property, but also in other areas such as the right to life. The term due process has been given the broader concept of meaning both the procedure and substance. Natural justice or fundamental justice in our view does not go beyond the procedural requirements of fairness.

The Minister of Justice took a similar stand in opposing the amendment, stating that the words "due process of law" would: 10

... very much limit the scope of the power of legislation by the Parliament and we do not want that; and it is why we do not want the words "due process of law".

If these reasons for opposing the N.D.P. amendment were adopted by the courts as the best evidence of parliamentary intention, the operation of s. 7 would be limited to ensuring procedural as opposed to substantive fairness. The implications of such a result will be explored more fully infra in the section of "fundamental justice".

\section{THE COMPONENTS OF SECTION 7}

Having considered the political statements which accompanied the rejection of the formulae employed in the Bill of Rights, it is now necessary to systematically examine the six components which comprise s. 7 . The components are found in the following phrases: (1) Everyone, (2) has the right to (3) life, (4) liberty, and (5) security of the person, and (6) the right not to be deprived thereof except in accordance with the principles of fundamental justice. These components shall now be considered individually.

\section{A. EVERYONE}

This word is important because it governs the scope of s. 7. One question which has arisen is whether it is broad enough to apply to both natural and artificial persons. At the committee stage, the N.D.P. proposed to replace "everyone" with "every individual" in order to limit application of the section to natural persons and to exclude corporations. In opposing the amendment, the Honourable Robert P. Kaplan, who was acting Minister of Justice at the time, indicated that the intention of the

8. The due process protection in the Canadian Bill of Rights is contained in s. 1(a) and is set out supra.

9. Supra n. 5 at January $27,1981,46: 32$.

10. Id. January $27,1981,46: 43$. 
Government in using the word "everyone" was to make the section applicable to corporations so far as the rights were capable of being enjoyed by artificial persons. He said: ${ }^{11}$

I would agree with Mr. Beatty that, if the rights provided in this clause, as amended, could apply to corporations, that they will do so if you use the word "everyone", but would not if $\mathrm{Mr}$. Robinson succeeds with his amendment. [to substitute the words "every individual"].

The N.D.P. amendment failed, which suggests that the politicians intended to give "everyone" a broad rather than narrow meaning.

Several pre-Charter cases support the broader interpretation of "everyone". In Union Colliery v. The Queen, ${ }^{12}$ the Supreme Court of Canada held that the word "everyone" as found in s. 213 of the Criminal Code $^{13}$ was properly applied to a corporation. Sedgewick J. stated: ${ }^{14}$

"Everyone" is an expression of the same kind as "person", and thereby includes bodies corporate unless the context requires otherwise.

In Rex. v. Hays, ${ }^{15}$ the Ontario Court of Appeal construed the word "everyone" as found in $\mathrm{s.} 138$ of the Criminal Code ${ }^{16}$ and held that it was wide enough to include corporations. A similar, broad interpretation was given to the word by the same court in The King v. Toronto Railway Company. ${ }^{17}$

In one Charter case bearing upon this point, Scollin J. of the Manitoba Court of Queen's Bench determined that the word "everyone" includes a corporation and, therefore, that a corporate accused was entitled to the legal rights in the Charter. ${ }^{18} \mathrm{He}$ considered the anomolies that would arise if corporate accused were treated differently than natural persons. ${ }^{19}$

. . . in the same proceedings arising out of the same criminal liability, one regime of specific substantive and evidentiary provisions would apply to the individual accused while another and less favourable regime would apply to their corporate co-accused: laws inconsistent with the Charter would be of no force or effect against one class of legal persons but would remain valid against another.

In a Charter case dealing with the meaning of the term "everyone" as found in s. 8, Cavanagh J. of the Alberta Court of Queen's Bench held that: ${ }^{20}$

\footnotetext{
... "everyone", as used in 5.8 should include all human beings and all entities that are capable of enjoying the benefits of security against unreasonable search. This then would include corporations.
}

In view of these judicial pronouncements, one can predict with some confidence that artificial as well as natural persons will be held to enjoy the rights declared in s. 7. The coverage of the Charter will in this respect be more expansive than the Canadian Bill or Rights which, apart from

11. Id. January 23, 1981, 44:9.

12. (1900) 31 S.C.R. 81 .

13. S.C. 1892, c. 29.

14. Supran. 12 at 88.

15. (1907) 14 O.L.R. 201 (Ont. C.A.).

16. (U.K.) 16 Victoria, c. 37.

17. (1905) 10 O.L.R. 26 (Ont. C.A.).

18. Re Balderstone (1983) 2 C.C.C. (3d) 37.

19. Id. at 45 .

20. Southam Inc. v. Hunter (1982) 68 C.C.C. (2d) 356 at 364. 
the differences that have already been noted, confers the equivalent of $s$. 7 rights only upon "individuals" and not, for example, trade unions. ${ }^{21}$

Section 7 rights should also be available to non-citizens deprived of a right by a Canadian official. ${ }^{22}$ One other question which has arisen concerning the scope of $s .7$ in immigration matters is whether the potential deprivation of a s. 7 right by authorities in another country constitutes "deprivation" under the Charter. In Singh v. Minister of Employment and Immigration, ${ }^{23}$ it was determined that the summary refusal of an application for immigrant status did not constitute a deprivation of "life, liberty or security of the person" because if such a deprivation were to occur at all, it would be at the hands of the authorities in the applicant's native country and not Canadian authorities. The Charter was held to apply only to the deprivation of rights by Canadian authorities applying Canadian law. Therefore, the applicant was not entitled to a hearing before having his application rejected.

Another important issue concerning the scope of "everyone" is whether a foetus is entitled to the right to life contained in s. 7. In an important recent case, ${ }^{24}$ Matheson J. of the Saskatchewan Court of Queen's Bench determined that the term "everyone" does not include the unborn and, therefore, that a foetus is not entitled to the constitutional right to life afforded by s. 7 . In rejecting the argument that a foetus ought to be invested with the right to life on conceptions, Matheson J. said:25

This suggestion appears to be tantamount to the creation of a legal fiction - not unknown to the law - that a potential human being be deemed a legal person contingent upon the potential human being achieving the status of an actual human being. A further difficulty with this thesis is that the law is generally concerned with actuality, not potentiality.

Matheson J. also rejected the argument that increased foetal viability due to technological innovation ought to extend the protection of the constitution. He said:26

Although rapid advance in medical science may make it socially desirable that some legal status be extended to foetuses, irrespective of ultimate viability, it is the prerogative of Parliament, and not the Courts, to enact whatever legislation may be considered appropriate to extend to the unborn any or all legal rights possessed by living persons. Because there is no existing basis in law which justifies a conclusion that foetuses are legal persons, and therefore within the scope of the term "everyone" utilized in the Charter, the claim of the Plaintiff must be dismissed.

This decision is under appeal and it will no doubt remain for the Supreme Court of Canada to ultimately determine whether the s. 7 right is conferred upon the foetus.

21. In Oil Chemical and Atomic Workers International Union, Local 16-601 v. Imperial Oil Ltd. (1961) 36 W.W.R. 385, as affirmed by the British Columbia Court of Appeal (1962) 33 W.W.R. 533, Whittaker J. held at p. 392:

Suffice it to say that if the plaintiff union has such right, it is not one of those human rights or fundamental freedoms which pertain to an individual and are recognized and declared by the Canadian Bill of Rights....

22. This point was argued by the N.D.P. member, Lorne Nystrom, before the Joint Committee; Special Joint Committee on the Constitution of Canada Proceedings January 23, 1981, 44:21.

23. (1982) 2 C.R.D. 550.20-.01.

24. Borowskiv. The Attorney General of Canada, unreported, October 13, 1983, No. QB793.

25. Id. at 24.

26. Id. at 31 . 


\section{B. HAS THE RIGHT}

A question of importance initially was whether the rights contained in s. 7 were retrospective. In Re Potma, ${ }^{27}$ Eberle J. held that as $\mathrm{s} .7$ contains no words that expressly require that the section be given retroactive effect and that as there was no necessary intendment to give the provision such effect, it was to apply prospectively only. Since leave to appeal to the Supreme Court of Canada was refused on May 17, 1983, it may be inferred that the rights secured in s. 7 are prospective from April 17, 1982.

Another issue which raises fundamental questions of political and legal theory is whether the rights that are provided in 5.7 are "negative" or "positive" rights. In his essay entitled "Two Concepts of Liberty", ${ }^{28}$ Isaiah Berlin defined the notion of negative freedom as follows: ${ }^{29}$

1 am normally said to be free to the degree to which no man or body of men interferes with my activity. Political liberty in this sense is simply the area within which a man can act unobstructed by others.

A negative right is thus the absence of coercion which impairs enjoyment of the right. It is to be contrasted with a positive right which would require the actual provision of the matter to which there is a right. An example will make the distinction clear. The Charter guarantees the right to life. Does this mean that the Charter is a barrier protecting everyone against state deprivation of their life, or does it mean that there is a positive obligation on the state to provide the goods and services necessary for the sustenance of life? Is it a statement of civil liberties or a manifesto of social welfare benefits?

This question has divided scholarly opinion on the true meaning of the American Declaration of Independence. Did Thomas Jefferson, when drafting the Declaration of Independence, intend to confer positive benefits upon the citizens or merely to restrain the state from interfering in their lives? In his paper on the Declaration of Independence, Professor Ronald Hamowy has observed: ${ }^{30}$

... that Jefferson understood the rights he enumerated as impelling others, either individually or collectively, to positive actions lies at the root of a whole series of misinterpretations of the meaning of the Declaration. ... Gilbert Chinard, for example, viewed Jefferson's choice of language as asserting "a new principle of government," one which placed a positive obligation on the civil magistrate to insure the happiness of his subjects. "I do not believe," Chinard wrote, "that any other State paper in any nation had ever proclaimed so emphatically and with such finality that one of the essential functions of government is to make men happy".

On the international level, the United Nations Human Rights Committee, established pursuant to the Optional Protocol to the United Nations Covenant on Civil and Political Rights, has asserted the "positive" nature of the rights contained in that document. The following commentary on the position of the Committee is taken from the review published by the International Commission of Jurists: ${ }^{31}$

27. (1982) 136 D.L.R. (3d) 69 (Ont. H.C.J.).

28. I. Berlin, Four Essays on Liberty (1969) 122.

29. Id. at 122.

30. See "Declaration of Independence" sections in the forthcoming Encyclopedia of American Political History.

31. 30 The Review (July 1983) 39. 
Of particular interest were the [Human Rights] Committee's comments on the right to life. These reiterated that this is the supreme right and is not to be narrowly interpreted. Protection of the "inherent right to life" requires states to adopt "positive measures". Elaborating on this, the Committee said it would be desirable for states parties "to take all possible measures to reduce infant mortality and to increase life expectancy, especially in adopting measures to eliminate malnutrition and epidemics"'.

The positive or negative nature of the rights set out in $\mathbf{s .} 7$ will be considered again in the sections dealing with the substantive rights to life, liberty and security of the person.

\section{LIFE}

The most fundamental of all rights, life, is secured by the Charter. A similar guarantee is found in several international instruments and in the American Bill of Rights. ${ }^{32}$ Yet, difficulties will arise in determining when life begins and under what circumstances it may be terminated. In the United States, it has been determined that "[l]ife begins in the contemplation of law as soon as an infant is able to stir in the mother's womb."'33

In Roe v. Wade, ${ }^{34}$ the United States Supreme Court determined that a state interest in the life of the unborn child arises after the end of the first trimester of pregnancy. Before that time, the privacy right of the mother overrides the right to life of the foetus. In consultation with his patient, an attending physician may determine, free from state regulation, that in his medical judgement a patient's pregnancy should be terminated. A subsequent abortion may take place without state interference. After the first trimester of pregnancy, however, a state may regulate abortion procedure to the extent that the regulation reasonably relates to the preservation and protection of maternal health. The Court went on to hold that: ${ }^{35}$

[i]f the state is interested in protecting foetal life after viability, it may go so far as to proscribe abortion during that period except when necessary to preserve the life or health of the mother.

In coming to this conclusion, the Court considered whether a foetus was a person entitled to the right to life guaranteed by the Fourteenth Amendment. It was held that the term "person" as used in the Fourteenth Amendment does not include the unborn. As discussed above, Matheson $\mathrm{J}$. of the Saskatchewan Court of Queen's Bench in Borowski ${ }^{36}$ reached a similar conclusion in defining the term "everyone" as found in s. 7.

In addition to dealing with the problems posed by abortion, euthenasia and capital punishment, the courts will be called on to determine whether the right to life gives rise to an entitlement to the necessaries essential for the maintenance of life. Is there a Charter right to social welfare as an incident to the right to life? ${ }^{37}$

32. See European Convention of Human Rights, Article 2; U.N. Covenant on Civil and Political Rights, Article 6; U.N. Declaration of Human Rights, Article 3; American Bill of Rights, Fifth and Fourteenth amendments.

33. State v. Forte(1943) 23 S.E. (2d) 842 at 843

34. 93 S.Ct. 705 (1973).

35. Id. at 706 .

36. Supran. 24.

37. This question has been raised before the Manitoba Court of Appeal which granted leave to appeal to determine whether a cancellation of social welfare benefits violated s. 7. Elliot v. Director of Social Services (Winnipeg Central) Court of Appeal of Manitoba, Matas, J.A., August 4, 1982. 
In the United States, "the right to life" has been held to comprehend a wide range of incidental activities. In Rosenblum v. Rosenblum, it was held that life and liberty ${ }^{38}$

... [includes] all personal rights and their enjoyment embracing the use and enjoyment of the faculties, acquiring useful knowledge, a right to marry, establish a home, and to bring up children, freedom of worship, conscience, contract, occupation, speech, assembly and press.

This very broad statement would, if adopted by the Canadian courts, greatly extend the operation of s. 7. However, not surprisingly, at least one Canadian judge has forecast that American authorities applied in the Charter context. In $R$. v. Carter, Brooke J.A. of the Ontario Court of Appeal commented on the applicability of American authorities in the following terms: ${ }^{39}$

No doubt the decisions of courts of the United States of America may be persuasive references in some cases under our new Charter but it is important that we seek to develop our own model in response to present values on the facts of cases as they arise rather than adopting the law of another country forged in response to past events.

\section{LIBERTY}

If the American experience is any guide, this component will generate a myriad of cases. The "right to life, liberty and the pursuit of happiness" was asserted to be a self-evident, natural right in the American Declaration of Independence. The right not to be ". . . deprived of life, liberty, or property without due process of law, ..." was restated in the Fifth Amendment and made applicable to the States in the Fourteenth Amendment to the American Bill or Rights. The incidents of liberty which have been recognized and protected by the American Courts are vast. Indeed, the editors of Corwin have observed that: ${ }^{40}$

[l]iberty under law extends to the full range of conduct which the individual is free to pursue, and it cannot be restricted except for a proper government objective.

The concept of liberty has been so broadly interpreted by the American Courts because judges have wished to extend the same constitutional safeguards against actions by the state governments as were already provided against the federal government by virtue of the first eight amendments. In order to enforce these standards against the states, the courts selectively incorporated most of the important rights and freedoms set out in the first eight amendments and applied them to the states through the liberty and due process provisions of the Fourteenth Amendment. This process of incorporation has been described by the leading American constitutional scholar, Laurence $\mathrm{H}$. Tribe, as follows: ${ }^{41}$

Many of the rights guaranteed by the first amendments have been selectively absorbed into the Fourteenth. Thus the due process clause has been held to protect the right to just compensation; the First Amendment freedoms of speech, press, assembly, petition, free exercise of religion, and non-establishment of religion; the Fourth Amendment rights to be free of unreasonable search and seizure and to exclude from criminal trials evidence illegally seized; the Fifth Amendment rights to be free of compelled incrimination and double jeopardy; the Sixth Amendment rights to counsel, to a speedy and

38. 42 N.Y.S. (2d) 626 at 630 .

39. Unreported, November 16, 1982, as quoted by D.C. McDonald J. in his "Judicial Digest" of cases decided under the Canadian Charter of Rights and Freedoms.

40. E.S. Corwin, The Constitution and What it Means Today (14th ed. 1978) 1 at 390.

41. See American Constitutional Law(1978) 567. 
public trial before a jury, to an opportunity to confront opposing witnesses, and to compulsory process for the purpose of attaining favourable witnesses; and to the Eighth Amendment right to be free of cruel and unusual punishments.

In deciding which Bill of Rights to "incorporate" the Court has said that it was searching for "principles of justice so rooted in the tradition and conscience of our people as to be ranked as fundamental" and thus "implicit in the concept of ordered liberty", or for those principles that were basic in our system of jurisprudence.

In Meyer v. State of Nebraska, the Supreme Court of Nebraska surveyed the expansive judicial character of "liberty" :42

While this Court has not attempted to define with exactness the liberty thus guaranteed, the term has received much consideration, and some of the included things have been definitely stated. Without doubt, it denotes not merely freedom from bodily restraint but also the right of the individual to contract, to engage in any of the common occupations of life, to acquire useful knowledge, to marry, establish a home and bring up children, to worship God according to the dictates of his own conscience, and generally to enjoy those privileges long recognized as essential to the orderly pursuit of happiness by free men.

Unlike in the United States, in Canada there is no need for the courts to resort to the process of selective incorporation in order to make any of the Charter rights applicable to either the federal or provincial governments. Since both levels are equally constrained by the Constitution, the courts will not have to broadly construe "liberty" to extend Charter protection from legislative excesses by either level of government. However, the same sort of pressure that has faced American judges might arise were a provincial legislature to employ a non obstante provision ${ }^{43}$ to prevent reliance on a particular Charter right or freedom. In such circumstances, the courts might be persuaded to broadly construe the concept of "liberty" in order to find the same right protected by s. 7 and thereby essentially circumvent the of fensive non obstante clause. ${ }^{44}$

While the Canadian courts will only rarely face this sort of pressure to expansively interpret the concept of "liberty", the very context in which the term is found conduces to a wide construction and makes the American decisions persuasive. There is a thematic link between "liberty" and the other Charter rights and freedoms. Many of them are prerequisites for the enjoyment of liberty, while others are the hallmarks of liberty in our society. There would be no liberty if the state did not defer to the fundamental freedoms and legal rights of its citizens, at least as these expressions are used in the Charter. To the extent that there is a link between $\mathrm{s.} 7$ and the other rights and freedoms that give practical expression to the concept of liberty, the procedural guarantees contained in $\mathrm{s.} 7$ may augment the protection of these other liberties. Where, for example, a court has found that some limitation of a Charter right or freedom

42. 262 U.S. 390 at 399.

43. Section 33(1) empowers a legislator to expressly declare that a law "shall operate notwithstanding a provision included in section 2 or sections 7 to 15 " of the Charter. (Emphasis added).

44. This would result in only temporary relief from a determined legislator who could deploy another non obstante provision. A broadly worded non obstante provision would not be liable to attack on this basis. However, a direct attack on overly broad non obstante provisions has been suggested by Professor Brian Slattery, who has argued that such provisions must be demonstrably justified as reasonable limits upon Charter rights and freedoms in accordance with the requirements of the express limitation contained in s. 1. See Comment on "Legislation" in [1983] 61 Can. Bar. Rev. 391. 
could be demonstrably justified in a free and democratic society it may, nevertheless, be persuaded that the application of the regulation in a particular case where that would result in a deprivation of liberty must be carried out in "accordance with the principles of fundamental justice". Even assuming that the phrase the "principles of fundamental justice" is narrowly interpreted to require only procedural, as opposed to substantive fundamental justice, the result would be to significantly affect the manner in which decisions in such cases could be made. One example should serve to underline the point. A scheme of film censorship deprives us of our liberty by limiting our freedoms of speech, expression and assembly. Even assuming some form of film censorship has been demonstrably justified as a limit on our fundamental freedoms, would not the particular scheme of deprivation have to conform to the principles of fundamental justice? In other words, are not affected citizens entitled to be heard by the censorship authority before a particular film is banned from the province? If the judicial answer to these questions were yes, the rules of natural justice would condition the exercise of power wherever constitutional rights or freedoms were to be limited, even though the general scheme of limitation itself was not constitutionally offensive. This line of reasoning would provide an important back-up argument to a claim that a scheme of legislation was unconstitutional.

Likewise, many of the procedural safeguards contained in the other legal rights sections of the Charter (sections 8 through 14) may be viewed as preconditions to the enjoyment of liberty. Indeed, the specific protections have been described by one judge as "a particularization of at least part of the procedural aspects of fundamental justice." 45

One counter argument, however, is that s. 7 is a general provision, while the fundamental freedoms and the other legal rights sections are specific. Therefore, far from augmenting the rights set out in the other sections, $\mathrm{s.} 7$ is a mere residual provision to be relied upon when nothing more specific can be found. This line of reasoning was followed by the British Columbia Supreme Court in $R$. v. Speicher, ${ }^{46}$ where Murray J. held that the fact that the principle of equality before and under the law is expressly dealt with in $\mathrm{s.} 15$ of the Charter indicates that it does not fall within s. 7, which deals with the general principles of fundamental justice.

In addition to the arguments that may be founded on the collocation of, or linkage between, s. 7 and the other Charter rights and freedoms, a broad construction of the concept of liberty is necessary to protect the many aspects of liberty that are not expressly enumerated in the Charter but which, nevertheless, are necessarily incidental to its existence. It is in searching for these examples that the American cases prove most useful.

Physical restraint is the most obvious form of deprivation of liberty and is unlawful in the absence of procedural due process. Since prisons are the most visible institutions that practice physical restraint, it is not surprising that cases concerning prison discipline and administration have arisen. Even in the pre-Charter era, members of the Supreme Court

45. R. v. Anson (1982) 68 C.C.C. (2d) 350 at 354 per Wetmore Co. Ct. J.

46. (1983) 2 C.R.D. 475-01. 
of Canada had concerned themselves with the relationship between physical restraint and liberty in the context of parole revocation and the developing duty of fairness in administrative law. In his dissenting judgment in Howarth v. National Parole Board, ${ }^{47}$ Dickson J. compared the relative freedom of a parolee to an inmate in the following terms: ${ }^{48}$

It cannot be argued successfully that the parolee remains in the custody of the warden of the prison or the Parole Board and that parole and revocation of parole are mere changes in the form of custody. Confinement in a cell and liberty under parole are simply not comparable. Though subject to the supervision of a parole officer, the liberty of a parolee is extensive and is extinguished by incarceration. By any test, incarceration upon revocation of probation is deprivation of freedom.

This line of reasoning has been followed by several judges faced with the question of whether revocation of parole without a hearing constitutes a deprivation of liberty not in accordance with the principles of fundamental justice. In $R$. v. Cadeddu; $R$. v. Nunery, Potts J. of the Ontario High Court determined that a prisoner on parole has $\mathrm{a}^{49}$

... conditional or qualified liberty to be at large during the term of his imprisonment. Although it [is] a qualified liberty which might be revoked, that, in my view is sufficient to attract the constitutionally mandated protections of $\mathrm{s} .7$ of the Charter. Accordingly, the Board, if it was not to violate the applicant's rights could revoke the applicant's parole only in accordance with the principles of fundamental justice.

The trial judge thus concluded that the applicants were entitled to an "inperson" hearing before their parole could be revoked..$^{50}$

A minimum sentence, where coupled with an absolute liability of fence, has in one case been held to deprive an applicant of liberty in violation of the principles of fundamental justice. In $R$. v. Campgana, Paradis, Prov. Ct. J. observed: 51

\begin{abstract}
In my view, to automatically deprive a citizen of his liberty by a process of absolute liability can only be seen as a "departure from the norm of living tradition".

If it can be said that absolute liability offences in themselves "violate fundamental principles of penal liability," one which causes a minimum term of imprisonment must be said to be in violation of principles of fundamental justice.
\end{abstract}

He went on to declare the legislation to be of no force or effect. This view was subsequently upheld by the British Columbia Court of Appeal in Reference Re Section 94(2) of the Motor Vehicle Act, (British Columbia). ${ }^{52}$ On the other hand, in $R$. v. Newall, ${ }^{53}$ Bouck J. of the British Columbia Supreme Court held that s. 5(2) of the Narcotics Control Act does not violate the right to liberty merely because it imposes a seven year minimum sentence upon conviction.

It is now necessary to briefly examine some of the interpretations of the term "liberty" which have been upheld by the American courts. The right to privacy has been held to be implicit in the concept of liberty as

47. (1975) 50 D.L.R. (3d) 349 (S.C.C.).

48. Id. at 358 .

49. (1983) 40 O.R. (2d) 128 at 139.

50. A similar finding that the qualified liberty of a parolee could not be extinguished without the protection afforded by s. 7 was made in Re Conroy, Unreported, April 28, 1983 (Ont. H.C.J.).

51. (1983) 70 C.C.C. (2d) 236 at 247.

52. (1983) 19 M.V.R. 63.

53. (1982) 70 C.C.C. (2d) 10. 
guaranteed by the Fourteenth Amendment. ${ }^{54}$ In Pavesich v. New England Life Insurance Company, it was held that ${ }^{55}$

[p]ersonal liberty includes not only freedom from physical restraint but also the right

"to be let alone", to determine one's mode of life, whether it shall be a life of publicity or of privacy....

The American courts have held also that freedom of contract is implicit in the concept of liberty and is protected by the due process requirement. ${ }^{56} \mathrm{~A}$ right closely allied to this is the liberty of the citizen to take up any livelihood or lawful occupation. Accordingly, it has been held that an individual has the liberty to pursue a chosen occupation free from unreasonable government interference. ${ }^{57}$

Liberty in the constitutional meaning includes absence of arbitrary and unreasonable restraint upon an individual in the conduct of his business and the use and enjoyment of property.

In educational matters, liberty has been held to protect students against expulsion without a fair hearing. The rationale for this decision was that the expulsion deprived the students of their property interests in education, and of their liberty interests in reputation, without due process. The courts have gone so far as to state that the "due process clause of the Fourteenth Amendment also forbids arbitrary deprivation of liberty" and that consequently "where a person's good name, reputation, honour or integrity is at stake, because of what the government is doing to them", ${ }^{58}$ the minimal requirements of the clause must be satisfied.

The notion that one's reputation is integral to one's liberty and, therefore, cannot be adversely affected by the state without due process has also had some impact on the termination of public employees. In Lyons v. Sullivan, ${ }^{59}$ it was held that defamation in the course of the termination of a government employee would entitle such an employee to due process protection and the opportunity to refute the stigmatizing charge. ${ }^{60}$ The further possibility that the right to reputation is incidental to "security of the person" rather than "liberty" is discussed in the next section.

Personal appearance has also been held to be an incident of liberty entitling individuals to choose their hairstyle and manner of dress except where the individual right to appearance is outweighed by the state interest in maintaining sanitary conditions and discipline in prisons or in establishing grooming standards for police and firemen. ${ }^{61}$

54. Careyv. Population Services International 431 U.S. 678.

55. 50 S.E. 68 at 68 . It should also be noted that during the committee stage the N.D.P. proposed to amend the section by including the following sentence: "Everyone has the right to protection against arbitrary or unreasonable interference with privacy." This amendment was defeated before the Joint Committee on January 27, 1981. See Special Joint Committee on the Constitution of Canada Proceedings 46:70.

56. Board of Regents of State Colleges v. Roth 408 U.S. 564 (U.S.C.A.).

57. Blauvet v. Beck 76 N.W. (2d) 738 at 741 (Nebraska S.C.).

58. Gross v. Lopez 419 U.S. 565 at 574 (U.S. Dist. Ct.).

59. 602 F. (2d) 7 (U.S.C.A.).

60. In this case, it was held that the tenured teacher-applicant had not been stigmatized by the request that he obtain a certificate from a psychiatrist attesting to his fitness. Therefore, his liberty right to reputation was not inf ringed.

61. Kellyv. Johnson 435 U.S. 238. 
In addition, liberty has been held by the American courts to include the right to travel and live and work where the individual wishes and the right to use public facilities and to travel on public highways and public vehicles subject to reasonable limitations in relation to the rights of others.

This brief review of American authorities is not intended to be a comprehensive account of the legion of decisions in which "liberty" has been construed. Rather, it is offered as support for the proposition that Canadian counsel will find their research efforts into American materials to be worthwhile.

\section{E. SECURITY OF THE PERSON}

This phrase, which is found in s. 1(a) of the Canadian Bill of Rights, is also affirmed as a right in several international instruments. ${ }^{62}$ It is not to be found, however, in the American constitutional documents.

A variant of this phrase enjoys an eminent place in the history of the common law. In his Commentaries on the Laws of England, ${ }^{63}$ Blackstone asserted that the right to "personal security" was one of the three principal or primary rights of the people of England; the other two being the right to personal liberty and the right to private property. The scope of "personal security" was described by Blackstone as follows: ${ }^{64}$

The right of personal security consists in a person's legal and uninterrupted enjoyment of his life, his limbs, his body, his health, and his reputation.

Blackstone described the right to personal security as a "positive" rather than "negative" obligation in the law. He described the obligation in the following terms: 65

The law not only regards life and member, and protects every man in the enjoyment of them, but also furnishes him with every thing necessary for their [sic] support. For there is no man so indigent or wretched, but he may demand a supply sufficient for all the necessities of life, from the more opulent part of the community, by means of the several statutes enacted for the relief of the poor....

To the extent that Blackstone accurately described the state of the common law, his work may serve as a powerful buttress to a Charter argument on the scope of security of the person.66 As the following paragraphs indicate, the concept of "personal security" at common law is much broader than the concept of "security of person" in the international conventions.

In litigation on the international level, "security of person" has been linked with "liberty". Commenting on Article 5 of the European Convention on Human Rights, Professor Fawcett has said:67

62. The international provisions are set out in Appendix $\mathrm{I}$.

63. W. Blackstone, Commentaries on the Laws of England (1979) 117.

64. Id. at 125 .

65. Id. at 127

66. The "positive" definition of security of the person is relied upon by the Law Reform Commission of Canada in Working Paper No. 26, Medical Treatment and the Criminal Law at 6 as follows:

Security of the person means not only the protection of one's physical integrity, but the provision of necessaries for its support.

67. J.E.S. Fawcett, The Application of the European Convention of Human Rights (1969) 58. 
Liberty and security are two sides of the same coin; if personal liberty spells actual freedom of movement of the person, security is the condition of being protected by the law in that freedom.

In his book on the same convention, Professor F.G. Jacobs has observed about Article 5 that: ${ }^{68}$

[t]he Article first states the general principle that "Everyone has the right to liberty and security of person". The meaning of "security" in this context is uncertain; the question was raised, but not resolved, in the East African Asians cases. On the normal principles of interpretation, the term "security" should be given a meaning independent of "liberty", but the remainder of the Article is concerned exclusively with deprivation of liberty.

The European Commission on Human Rights has taken a narrow view of the scope of "liberty and security of person" based on the context in which these rights are found in Article 5 of the Convention. In Adler v. Federal Republic of Germany, the Commission held: 69

The term "liberty and security of person" in this provision must be read as a whole and, in view of its context, as referring only to physical liberty and security of the person.

"Liberty of person" in Article 5(1) thus means freedom from arrest and detention, and

"security of person" the protection against arbitrary interference with this liberty.

The concept of liberty has thus been defined in terms of the freedom from physical restraint. This is in sharp contrast to the expansive construction given to this term by the American courts as considered above. The phrase "security of person" has been narrowly interpreted as playing a supportive role in limiting arbitrary state interference with liberty so defined. The result is that a very narrow protection is afforded by these terms. It is important to emphasize that the restrictive interpretation makes sense given the statutory context in which the concepts are located. In Article 5, "liberty and security of person" are juxtaposed with provisions that allow limitation of these rights to secure the detention of individuals. It is, therefore, logical to construe the concepts as being designed to ensure freedom from arbitrary physical restraint. In the Charter, on the other hand, the same terms are not trapped by their context in the same confining way. Therefore, European precedents will be of only limited assistance as aids to construction. Instead, the concept of "security of the person" will take on a unique Canadian meaning.

The potentially broad sweep of the phrase "security of the person" was anticipated by Dr. Strayer, Q.C. in his evidence before the Joint Committee. ${ }^{70}$ When he was asked what the government had intended by the phrase he replied: ${ }^{72}$

The term "security of the person" ... could be interpreted in a very broad sense so the term "security" could cover matters of a ... contractual or property nature.

This was precisely the meaning given to the phrase in one of the most famous early Charter cases. In The Queen in Right of New Brunswick v. Fisherman's Wharf Ltd., ${ }^{73}$ Dickson J. of the Court of Queen's Bench of

68. F.G. Jacobs, The European Convention on Human Rights, (1975) 45.

69. See Application No. $5573 / 72$ and $5670 / 72$ reported in Yearbook of the European Convention of Human Rights.

70. I have discussed the admissibility of political statements as extrinsic evidence in Charter cases in "The Limitation of Liberty" (1982) U.B.C. L. Rev. Charter Edition 105.

72. Supran. 5 at January $27,1981,46: 33$.

73. (1982) 135 D.L.R. (3d) 307. 
New Brunswick held that, notwithstanding the absence of an express guarantee, the Charter implicitly protects the right to property as an incident of security of the person. Dickson J. said: ${ }^{74}$

\begin{abstract}
The Charter is silent in specific reference to property rights. In that circumstance it can only be assumed, in my view, that the expression "right to . . . security of the person" as used in s. 7 must be construed as comprising the right to enjoyment of the ownership of property which extends to "security of the person" and that in consequence the further words of s. 7 viz. "and the right not to be deprived thereof except in accordance with the principles of fundamental justice" must extend to the right not to be deprived of property rights which tend to extend to the security of the person.
\end{abstract}

Despite the initial excitement over this judgement, for several reasons it is unlikely to stand the test of time. First, Dickson J. came to this conclusion without having heard argument by counsel as to the applicability of the Charter. Second, his comments on the Charter were obiter. ${ }^{75}$ Finally, while the decision was affirmed on appeal, on non-Charter grounds, LaForest J.A. of the New Brunswick Court of Appeal pointed out that the "security of property" was not expressly protected by the Charter in order not to frustrate "regulatory schemes ovbiously intended to reallocate rights and resources" which of necessity affect vested rights. ${ }^{76}$

In Joseph L. Axler v. Her Majesty the Queen, 77 Mahoney J. of the Federal Court Trial Division tersely rejected the argument that there is a Charter-protected right to property. He struck out a Statement of Claim in which it was pleaded, among other things, that the collection efforts employed by the Minister of National Revenue violated the Plaintiff's right to property under s. 7. Mahoney J. categorically stated that the Charter did not protect property rights and, therefore, that the Statement of Claim failed to disclose a cause of action.

Further, in Becker v. The Queen in Right of Alberta, ${ }^{78}$ it was held by Montgomery J. of the Alberta Court of Queen's Bench that ${ }^{79}$

[t]he word "seizure" in section 8 does not encompass real property rights because section 7 does not provide a right to the enjoyment of property.

This decision was affirmed on appeal and Lieberman J.A., who spoke for the Court of Appeal, stated:80

The word "seizure" is used in 5.8 in association, admittedly in the disjunctive form, with the word "search". It is our view that the protection afforded by s. 8 does not extend to the taking of real property by expropriation.

Given the political evolution of the Charter, and the fact that the words "enjoyment of property" were intentionally left out of s. 7, and the further fact that there is an ongoing political debate as to whether this right ought to be constitutionally entrenched (which implies that the right
74. Id. at 315 . Undeclared Rights"'(1983) I Can. Bar. Rev. 398.
76. (1982) 44 N.B.R. (2d) 201 at 214.
77. Unreported, 31 May 1982, Mahoney J. (F.C.T.D.).
78. (1983) 45 A.R. 36.
79. Id. at 42.
80. Id. at 37 .

75. The reasoning of Dickson J. is criticized by G.J. Brandt in "Canadian Charter of Rights and Freedoms-Right to Property as an Extension of Personal Security-Status of 
is not already protected), it is unlikely that the courts will fashion a right to property in the near future.

Regarding the right to reputation, on the other hand, if the courts can be convinced that Blackstone was correct in considering this right to be an incident of personal security and hence of security of the person, a powerful new weapon may be forged. Blackstone's rationale is as follows: ${ }^{81}$

The security of his reputation or good name from the arts of detraction and slander, are rights to which every man is entitled, by reason and natural justice; since without these it is impossible to have the perfect enjoyment of any other advantage or right.

Assuming that the phrase "the principles of fundamental justice" is given even its minimal meaning as procedural rather than substantive fundamental justice, it is arguable that an individual or corporation which stood the risk of having its good name or reputation impugned by some state action, would be entitled to benefit from the procedural protection afforded by the rules of natural justice. Such a development would buttress the developing duty of fairness and in some cases would provide an alternative ground for insisting on a fair procedure even if there is no right to property implicit in the Charter. In cases involving licence revocation, loss of public office or expulsion from school, there would be a right not to be deprived of one's good reputation except in accordance with the principles of fundamental justice. One example may suffice to illustrate the point. In its decision in Melsness v. The Department of Social Services and Community Health ${ }^{82}$ the Court of Appeal of Alberta determined that the Director of Child Welfare, who was the holder of a public office, was not entitled to be treated fairly upon his termination from his public office because he had been appointed to hold his of fice at pleasure as defined by the Interpretation Act. The Court held that the Minister's right to dismiss was a right to dismiss arbitrarily, without reasons. ${ }^{83}$ Yet, if "security of the person" includes the right to reputation, then the statutory concept of appointment during pleasure would violate s. 7 to the extent that it permits the deprivation of public of fice without a prior hearing in circumstances where the public announcement of the grounds for the revocation of appointment would adversely affect the professional reputation of the of fice holder.

In Charter litigation, the right to security of the person has been held to include the right to adequate medical treatment for prisoners. In

81. Supran. 63 at 130 .

82. Melsness v. The Minister of Social Services and Community Health (1982) 18 Alta. L.R. (2d) 314 (Alta. C.A.).

83. The right to dismiss arbitrarily and without reasons was apparently conceded in argument, notwithstanding the fact that Laskin C.J. had recently ruled, albeit by obiter comment in Re Nicholson (1978) 88 D.L.R. (3d) 671 at 679, that:

[t]he old common law rule, deriving much of its force from Crown law, that a person engaged as an office holder at pleasure may be put out without reason or prior notice ought itself to be re-examined. It has an anachronistic flavour in the light of collective agreements, which are pervasive in both public and private employment, and which of fer broad protection against arbitrary dismissal in the case of employees who cannot claim the status of office holders. 
Collin v. Lussier, ${ }^{84}$ Decary J. found as a fact that the transfer from a medium to a maximum security penal institution would ${ }^{85}$

... by increasing the applicant's anxiety as to the state of his health, . . . [be] likely to make his illness worse, and by depriving him of access to adequate medical care . . . [was] in fact an impairment of the security of his person.

The failure to inform the prisoner of the offence he had committed and to give him an opportunity to defend himself before transferring him for disciplinary reasons constituted a violation of his constitutional rights. The trial judge held: 86

In a question involving transfer of an inmate to a penitentiary with a greater level of security than that in which he is being held, when the effect of such a transfer is to impair security of the person, this is no longer merely an administrative decision, but is a decision involving constitutional law, and fundamental justice must accordingly be observed.

In the result, Decary J. awarded the applicant damages for the injury suffered by him as a result of the transfer, including $\$ 15,000.00$ for "denial of security of his person".

The phrase "security of the person" may also be construed as conferring protection on individuals against non-voluntary medical and psychiatric treatment ${ }^{87}$ and may reinforce the prohibition against unreasonable searches of the person set out in $\mathbf{s .} 8$.

\section{F. THE PRINCIPLES OF FUNDAMENTAL JUSTICE}

While this concept is not new in Canadian legal drafting, the principles of fundamental justice received very little judicial attention in the preCharter era. This fact explains why many of the witnesses appearing before the Joint Committee requested the government to clarify its intentions by substituting either the concept of "natural justice" or "due process". These efforts to substitute the known for the unknown were unsuccessful, however, and it is now for counsel and the courts to struggle with the interpretation.

One starting point may be the Canadian Bill of Rights, which contains the phrase "principles of fundamental justice". Section $2(\mathrm{e})^{88}$ provides:

Every law of Canada shall, unless it is expressly declared by an Act of the Parliament of Canada that it shall operate notwithstanding the Canadian Bill of Rights, be so construed and applied as not to abrogate, abridge or infringe or to authorize the abrogation, abridgement or infringement of any of the rights or freedoms herein recognized and declared, and in particular, no law of Canada shall be construed or applied so as to ... (e) deprive a person of the right to a fair hearing in accordance with the principles of fundamental justice for the determination of his rights and obligations.

84. February 24, 1983, Federal Court of Canada Trial Division, No. T-9227-82.

85. Id. at 21 .

86. Id. at 23 .

87. The Law Reform Commission of Canada concluding in its report, Protection of Life: Sterilization, Working Paper 24, that non-voluntary sterilizations contravene a basic human right. It also reflected on the inadequacy of third party consent to such procedures in the pre-Charter era. The Commission commented at page 53:

The Canadian Bill of Rights further guarantees security of the person and the right not to be deprived thereof except by due process of law. This may be interpreted to mean that sterilization may not be performed on the mentally handicapped except according to the law of Canada.

In the regime imposed by 5.7 , this should now require procedural due process and not merely compliance with the law of Canada.

88. Supra n. 3. Emphasis added. 
The Supreme Court of Canada considered the phrase in Duke v. The Queen, ${ }^{89}$ and Fauteux, C.J.C. for the unanimous court stated: ${ }^{90}$

Without attempting to formulate any final definition of those words, 1 would take them to mean, generally, that the tribunal which adjudicates upon his rights must act fairly, in good faith, without bias and in a judicial temper, and must give him the opportunity adequately [sic] to fairly state his case.

There is an important difference between the wording of s. 2(e) of the Bill of Rights and s. 7 of the Charter which may bear on the applicability of the decision in Duke. The Bill of Rights section speaks of a "fair hearing in accordance with the principles of fundamental justice". The Charter, however, makes no reference to a fair hearing. Instead, s. 7 simply states that one is not to be deprived of "life, liberty, or security of the person" except in accordance with the principles of fundamental justice. It is arguable, therefore, that while the Canadian Bill of Rights imposed a merely procedural protection, the Charter is designed to go further and to impose a substantive limitation on the deprivation of the life, liberty or security of the person. In other words, fair procedure would not suffice. The very statute authorizing the act of deprivation would itself have to be just.91

An extreme example will illustrate the important difference. Suppose that Parliament were to impose the death penalty as the minimum punishment for those convicted of theft under two hundred dollars. Would this be in accordance with the principles of fundamental justice? Even if an eminently fair procedure were employed at the thief's trial, would the courts stand by and allow Parliament to so radically limit the right to life? More accurately, could the court, without doing violence to the plain words of s. 7, find that such a law was fundamentally unjust and that it conflicted with the substantive, fundamental principle of justice that the punishment must be commensurate with the crime? This example underlines one of the most difficult questions arising out of s. 7 - have the courts been given the power to review substantive law and to declare unjust laws unconstitutional?

89. [1972] S.C.R. 917.

90. Id. at 923 .

91. In the United States, the courts seized the power to impose substantive due process pursuant to the due process provisions of the 5th and 14th Amendments. During the "heyday" of substantive due process (1900-1937), the concept was employed to frustrate state intervention in the economy. The editors of Corwin's The Constitution and What it Means Today (14th ed. 1978), have observed at p. 389 that:

... this clause [the Fifth Amendment] was employed frequently to challenge the substantive content of legislation, or in other words to require that Congress exercise its powers "reasonably", that is to say, reasonably in the judgement of the Court. (Emphasis added). In 1963 the Supreme Court rejected the interventionist role it had been playing in the economy of the nation. In Ferguson v. Skrupa 372 U.S. 726 at 731 , Justice Black stated:

We refuse to sit as a "superlegislature to weigh the wisdom of legislation and we emphatically refuse to go back to the time when courts used the Due Process Clause [sic] to "strike down state laws, regulatory of business and industrial conditions, because they may be unwise, improvident, or out of harmony with a particular school of thought". . . Whether the legislature takes for its textbook Adam Smith, Herbert Spencer, Lord Keynes or some other is no concern of ours.

While the U.S. courts have now largely refrained from using the due process provisions to second-guess economic policy, the concept has had an important role in the promotion of civil liberties and civil rights. A consideration of these developments, however, is beyond the scope of this paper. 
A review of the evidence before the Joint Committee is instructive as to the intention of the draftsmen. When the Minister of Justice was asked what was meant by the phrase "principles of fundamental justice", he referred the question to the "drafter", Deputy Minister Roger Tassé, Q.C. who said: 92

\begin{abstract}
We assume that the Court would look at that much like a Court would look at the requirements of natural justice, and the concept of natural justice is quite familiar to courts and they have given a good deal of specific meaning to the concept of natural justice. We would think that the Court would find in that phraseology principles of fundamental justice a meaning somewhat like natural justice or inherent fairness. Courts have been developing the concept of administrative fairness in recent years and they have been able to give a good deal of consideration, certainly to these sorts of concepts, and we would expect they could do the same with this.
\end{abstract}

The equivalence of the phrases "natural justice" and "the principles of fundamental justice" was also stressed by the Assistant Deputy Minister of Justice, Dr. B.L. Strayer, Q.C. who said:93

The term "fundamental justice" appears to us to be essentially the same thing as natural justice. ... [F]undamental justice or natural justice both involve procedural fairness and that is the content of them.

The requirements of natural justice have certainly have been pretty well defined over the years by the courts. The term "fundamental justice" has not been used very much in legislation, although it does appear in the Canadian Bill of Rights. But we have assumed it meant about the same thing. Those two terms can be contrasted to due process.

In the Charter cases which have been decided to date, there has been an interesting divergence in views on the question whether the term "fundamental justice" confers a power to review substantive or merely procedural aspects of legislative and administrative action. The most striking example of the "substantive fundamental justice" approach is found in the British Columbia Court of Appeal decision in Reference Re Section 94(2) of the Motor Vehicle Act (British Columbia) ${ }^{94}$ where in a per curiam judgement, it was determined that ${ }^{95}$

\footnotetext{
... the meaning to be given to the phrase "principles of fundamental justice" is that it is not restricted to matters of procedure but extends to substantive law and that the Courts are therefore called upon, in construing the provisions of s. 7 of the Charter, to have regard to the content of legislation. Applying the reason of Mr. Justice Dickson in the Sault Ste. Marie [sic] case, ${ }^{96}$ it is our opinion that s. 94(2) of the Motor Vehicle Act is inconsistent with the principles of fundamental justice.
}

In the result, the Court decided that s. 94(2) was inconsistent with the Charter and declared accordingly.

In $R$. v. Stevens, ${ }^{97}$ the Ontario Court of Appeal "assumed without deciding the question", that the Charter permitted the Court to review

92. Supran. 5, November 12, 1980, 3:79.

93. Supra n. 5, January 27, 1981, 46:38-39; see also the comment by Dr. B. Z. Straya at 56.

94. (1983) 19 M.V.R. 63.

95. Id. at 70.

96. R. v. Sault Ste. Marie [1978] 2 S.C.R. 1299. In that case, Dickson J. dealt with the difficulty of strict liability of fences and concluded at page 1311 that

[a]rguments of greater force are advanced against absolute liability. The most telling is that it violates fundamental principles of penal liability.

This is the conclusion that caught the attention of the Court of Appeal.

97. (1983) 2 C.R.D. 125.50-01. 
the substantive content of the legislation in question but determined, nevertheless, that s. 146(1) of the Criminal Code ${ }^{98}$ was not contrary to s. 7.

The opposite view was taken in Re Jamieson, ${ }^{99}$ where Durand J. of the Quebec Superior Court (Criminal Division) rejected an argument that s. 7 rights were infringed by the statutory provisions that require persons charged with an indictable offence to attend for the purposes of finger printing. In coming to the conclusion that the Identification of Criminals Act did not deprive the accused of life, liberty or security of the person, Durand J. had to consider the meaning of the phrase "principles of fundamental justice". He concluded that the concept was identical to natural justice: 100

It appears to be established now that the effect of this section is procedural and not substantive in that it may be used to impugn the form of the infringement of the guaranteed rights but not the substance thereof. . . . It is also established that the words "fundamental justice - justice fondamentale" are synonymous with "natural justice - justice naturelle".

A similar finding was made in $R$. v. Holman, ${ }^{101}$ where it was held that the phrases "the principles of fundamental justice" and the "rules of natural justice" were synonymous. ${ }^{102}$ In arriving at this conclusion, the trial judge relied upon the Proceedings of the Joint Committee and the statements of Dr. Strayer as set out supra, to divine the intention of Parliament. He justified this reliance upon extrinsic evidence as follows: ${ }^{103}$

... I have no great reluctance in taking notice of the statements of a federal civil servant testifying before a legislative committee when it relates to the "intent" of a piece of legislation. Far too of ten we are kept in the dark more than we care to be with respect to the "intention of Parliament".

The view that fair procedure and not fair law is required by s. 7 also has found favour with the Court of Appeal of Manitoba in The Queen v. Hayden. ${ }^{104}$ In that case, Hall J.A. firmly rejected the notion of substantive fundamental justice: 105

My reading leads me to the conclusion that the phrase "principles of fundamental justice" in the context of section 7 and the Charter as a whole does not go beyond the requirement of fair procedure and was not intended to cover substantive requirements as to the policy of the law in question. To hold otherwise would require all legislative enactments creating of fences to be submitted to the test of whether they of fend the principles of fundamental justice. In other words, the policy of the law as determined by the legislature would be measured against judicial policy of what of fends fundamental justice. In terms of procedural fairness, that is an acceptable area for judicial review but it should not in my view, be extended to consider the substance of the of fence created.

98. That section of the Criminal Code creates the crime of having sexual relations with a girl under fourteen years of age and precludes mistake as to the age of the girl from being a defence.

99. (1983) 70 C.C.C. (2d) 430 .

100. Id. at 438.

101. 28 C.R. (3d) 378 (B.C. Prov. Ct.).

102. The view that $\mathrm{s} .7$ provides for procedural and not substantive fundamental justice was also expressed in: Re Balderstone (1982) 2 C.C.C. (3d) 37 at 47, (Man. Q.B.); R. v. Anson (1982) 68 C.C.C. (2d) 350 (Co. Ct. Vancouver); and R. v. Macintyre (1982) 69 C.C.C. 162 at 166, (Alta. Q.B.).

103. Supran. 101 at 390.

104. October 5, 1983, Man. C.A.

105. Id. at 3. 
Given the diametrically opposing positions which have been taken on this important issue, it will remain for the Supreme Court of Canada to determine whether Canadians may resort to the courts to obtain substantive fundamental justice. Notwithstanding the evident intentions of the draftsmen to provide for the review of the procedural and not the substantive aspects of legislation, the stark reality is that they did not employ the time-tested phrase, "natural justice", but used a new and undefined phrase, "fundamental justice". Whatever they may have intended they did not write what they meant. The door is, therefore, open to substantive fundamental justice, and unless and until it is closed by the Supreme Court of Canada, the courts can expect to be called upon to decide whether legislators have acted justly.

Regardless whether s. 7 imports a substantive element, it is clear that at a minimum, it has constitutionally entrenched procedural fairness. A brief review of Charter litigation reveals that the rules of natural justice are being brought to bear to protect against deprivation of life, liberty, and security of the person.

For example, the right to a hearing has been upheld in several cases. ${ }^{106}$ Yet, while it is assumed in most cases that there is a requirement of fair procedure, the precise elements of the procedure vary from case to case depending upon the facts. There is a sliding scale of procedural fairness under $\mathrm{s.} 7$ just as there is with the related common law concepts of the rules of natural justice and the duty of fairness. Therefore, it is not to be assumed that an "in-person" hearing is necessary in every case to satisfy the principles of fundamental justice. ${ }^{107}$

It has been held that $\mathrm{s}$. 7 contemplates a right to counsel where legal representation would be necessary to allow a person to mount an ade-

106. (1) In R. v. Cadeddu (1982) 40 O.R. (2d) 128 (Ont. H.C.J.), it was held that a prison inmate on parole is at liberty and that the Parole Board is required to act in accordance with the principles of fundamental justice by granting a hearing prior to revoking parole.

(2) In Re Nunery (1983) 9 W.C.B. 105 (Ont. H.C.J.), R. v. Cadeddu was followed. Section 7 was violated when the applicant's parole was revoked without first affording him a hearing. "Fundamental justice in this case of necessity implies the application of the rule of audi alteram partem in a meaningful way." Even though legislation did not require a hearing, one was required by the Charter.

(3) In Re Taubler [1983] Ont. D. Crim. Conv. 5930-03 (Ont. H.C.J.), Re Balderstone (1982) 2 C.C.C. (3d) 37 (Man. Q.B.) was applied. Section 7 is not violated by the refusal of the Crown to grant a hearing to counsel for the accused before proceeding by direct indictment.

(4) In Re Conroy [1983] Ont. D. Crim. Sent. 7034-03 (Ont. H.C.J.), it was held that a Parole Board condition that a parolee abstain from the consumption of alcohol did not deprive the parolee of life or liberty. The general position stated in Cadeddu was affirmed by the trial judge who asserted that a parolee is entitled to a hearing before the revocation of his parole. The waiver of the right to a hearing without full knowledge of the rights including the right to counsel is not an effective waiver. "A parolee enjoys a very real although conditional or qualified right or privilege to be at large during the term of his imprisonment, and this qualified liberty is sufficient to attract the protection afforded by this section."

(5) In $\operatorname{Re}$ Lowe (1983) 9 W.C.B. 349 (B.C.S.C.) the foregoing decisions were followed and extended. The court held that the inmate was entitled to an "in-person" hearing and that the exclusion of the inmate for part of the hearing rendered the revocation order invalid.

107. In Soenen v. Thomas (August 23, 1983, Alta. Q.B., McDonald J.) it was held that the director of a remand centre was under no obligation to give prisoners a hearing before altering the rules of the institution. 
quate defence to allegations which, if proved, would warrant discipline. ${ }^{108}$ On the other hand, it has been held that the Charter right of an accused to learn of the case he has to meet, does not empower a magistrate at a preliminary inquiry to order the opening of a sealed packet containing documents relating to an application for an authorization to intercept private communication. ${ }^{109}$ The right to cross examine witnesses will depend on the circumstances. ${ }^{110}$ There is a right to have a decision made by the persons who have heard the evidence and it is invalid for a member of a tribunal who was absent from the hearing to cast a deciding vote. ${ }^{111}$ Finally, s. 7 provides the basis upon which the courts may exercise jurisdiction to prohibit abuses of process. ${ }^{112}$

Based on the foregoing cases, it is clear that the standards of procedural fundamental justice will be found in the common law doctrines of natural justice and the duty of fairness. Several consequences flow from the fact that the Charter now enshrines these common law rights.

First, the right to fair procedure is no longer a merely implied statutory right to be granted in the absence of express, contrary words. It is a constitutional right and legislation is inoperative to the extent that it purports to empower the deprivation of life, liberty or security of the person without procedural fairness. It is no longer up to the common law to

108. In Joplin v. Chief Constable of the City of Vancouver (1982) 2 C.C.C. (3d) 396 (B.C.S.C.), it was held that a constable was entitled to be represented by counsel before a disciplinary tribunal. At 402, McEachern C.J.S.C. remarked on the applicability of the Charter in the following terms:

... in my view, "fundamental" in this case is an unnecessary adjective because fundamental justice is justice and fairness, nothing more and nothing less. I prefer to approach this case from that point of view as I think the results will be the same under the general law without recourse to the Charter.

109. R.v. Diotte (1982) 40 O.R. (2d) 469; affd. Ont. C.A., May 4, 1983.

110. (1) In Re Schmidt (1983) 9 W.C.B. 330 , it was held that the denial of the right to cross examine a deponent to an affidavit adduced in the context of an extradition hearing did not violate the fugitive's rights under s. 7.

(2) In Re Voss (May 13, 1983, B.C.S.C., Tyrwhitt-Drake J.), the Schmidt result was affirmed on the ground that the purpose of an extradition hearing is not to determine the guilt or innocence of the fugitive, but only to determine whether there is a case to be met in the domestic courts of the state demanding the extradition. Therefore, fundamental justice does not require that the fugitive be given an opportunity to cross-examine the deponent of an affidavit filed in support of the application for extradition.

(3) On the other hand, in R. v. Clarke (1982) 3 C.R.R. 271 (B.C.S.C.), it was held that the testimony of a witness at a preliminary inquiry could be read in at trial notwithstanding the fact that the witness was not present to be cross-examined, on the basis that the accused had had a full right of cross-examination at the preliminary inquiry.

111. Re Mason (1983) 10 W.C.B. 303 (Ont. H.C.J.).

112. (1) In $R e$ Bruneau (1982) 69 C.C.C. (2d) 200 (B.C.S.C.), it was held that s. 7 provides a foundation for the court's power to prevent an abuse of process.

(2) In R. v. Vermette (1982) 1 C.C.C. (3d) 477 (Que. S.C.), a stay of proceedings was directed to remedy the prejudice done to an accused when the Premier of Quebec made highly publicized statements attacking the credibility of a defence witness.

(3) In R. v. Hartley (1983) 9 W.C.B. 384 (Sask. Prov. Ct.), it was held that the relaying of an identical information after the accused had been discharged following a preliminary inquiry and the attempt to put the same evidence before another magistrate on the view that the earlier magistrate had made an error of law in discharging the accused is an abuse of process. Such a process was nothing less "than judge shopping and is vexatious and oppressive to the rights of the accused." Section 7 affords an accused the right to claim its protection against abusive or oppressive proceedings. 
remedy the omission of the legislature, for the Constitution now ensures that goal will be obtained.

Second, the constitutional right to fair procedure exists regardless of the function being performed by the body charged with administering a scheme that could result in the deprivation of life, liberty or security of the person. The characterization of functions as a threshold inquiry has been removed. Everyone is capable of obtaining Charter relief against any state agency depriving persons of life, liberty or security of the person. However, the precise procedure required to satisfy the constitution may depend on the type of decision-making undertaken by the tribunal. It may well be that a higher standard of fairness will be required of a tribunal exercising judicial or quasi-judicial functions than one exercising administrative or legislative ones. The characterization of functions may not, therefore, be obsolete; it will simply be reached at a different stage in the argument.

Third, a decision made in violation of the principles of procedural fundamental justice would be unconstitutional and, therefore, void $a b$ initio rather than merely voidable. A tribunal would lack constitutional jurisdiction to violate the principles of procedural fundamental justice. Thus, cases like Harelkin v. The University of Regina ${ }^{113}$ would be decided differently under the Charter, assuming that expulsion from university constitutes a deprivation of liberty or security of the person. In Harelkin, the admitted failure of a first-level tribunal to comply with the rules of natural justice did not result in its proceedings being declared a nullity because the defect could be cured on appeal to a university appeal body. The natural justice defect did not render the first decision a nullity. Under the Charter it would not be possible for an appellate, administrative tribunal to cure the failure of the first-level tribunal to provide procedural fundamental justice. This is so because the first-level hearing would be unconstitutional and its determinations, void ab initio. In the absence of a constitutional foundation for the exercise of authority by the first tribunal, it could have no jurisdiction at all.

Fourth, the Charter will limit the operation and effectiveness of privative clauses. A privative clause purporting to preclude judicial review of a decision where an individual had been deprived of life, liberty or security of the person, without procedural fundamental justice, would itself be unconstitutional. Just as a privative clause is ineffective to preclude review of breaches of the rules of natural justice, so would such clauses fail to immunize a tribunal that failed to afford procedural fun- 
damental justice to an affected person. ${ }^{115}$ Further, even privative clauses that purport to preclude review for error of law within jurisdiction would be ineffective where the error of law would result in the deprivation of some other constitutional right or freedom. This is so because any determination as to the applicability of the Charter is a matter of constitutional law and is, therefore, by definition, a jurisdictional matter and beyond the protection afforded by a privative clause. In other words, the power to decide a matter involving constitutional rights cannot be conferred exclusively upon an inferior administrative tribunal. An example of a power to affect constitutional rights, is the power conferred upon the Alberta Public Service Employee Relations Board pursuant to s. 21(1)(1) of the Public Service Employee Relations Act R.S.A. 1980 c. P-33, which provides:

A person employed by an employer

(1) who in the opinion of the Board should not be included in a bargaining unit or any other unit for collective bargaining by reason of the duties and responsibilities he has to his employer,

shall not be included in a bargaining unit or any other bargaining unit for collective bargaining.

This section empowers the Board to determine whether any particular employee will be entitled to engage in collective bargaining or not. Ostensibly, the Board has exclusive jurisdiction to make this determination and, as the Supreme Court of Canada determined in Re Alberta Union of Provincial Employees et al. and Board of Governors of Olds College, ${ }^{116}$ unless the decision of the Board is patently unreasonable, the courts will not intervene to quash the decision. However, since the Board is required to make a decision that will affect, and possibly limit the fundamental freedom of association of concerned employees, the privative clause barrier will not be effective to preclude review except for patent unreasonability. Even though the board has authority to decide the issue, its decision on the constitutional rights of the employees cannot be beyond review by the courts and must be correct in law. To paraphrase the crisp words of Freedman J.A. in Parkhill Bedding and Furniture Ltd. ${ }^{117}$ an administrative tribunal does not have the right to be wrong on a question affecting constitutional rights. Such a power cannot be conferred by a privative clause.

115. This assumes, of course, that the legislator has not deployed a non obstante clause. In Re Jack and the Queen (1983) 1 C.C.C. (3d) 193, Steele J. of the Newfoundland Supreme Court Trial Division, determined that a privative clause purporting to preclude review by way of habeus corpus was incapable of depriving an individual of having the constitutionality of his detention determined pursuant to s. 10(c) of the Charter. At p. 199 Steele J. said:

I have come to the conclusion that the applicant is entitled to have the legality of his detention determined on an application for a writ of habeus corpus. I have reached this conclusion on the basis that s. $\mathbf{4 5 9 . 1}$ is not applicable to the facts before me and, secondly, by virtue of the common law and s. 10(c) of the Charter of Rights the applicant has the right to have the validity of his detention determined by way of an application for habeus corpus.

116. 136 D.L.R. (3d) 1.

117. (1961) 26 D.L.R. (2d) 589 (Man. C.A.). 


\section{CONCLUSION}

The elements of s. 7 are capable of wide operation. A liberal construction of the terms "life, liberty and security of the person" would give the courts jurisdiction to inquire into a broad range of relationships between the state and both natural and artificial persons. If s. 7 imports substantive fundamental justice into our legal system, the courts will be given access to territory that was previously the exclusive domain of Parliament and the Legislatures. The wisdom and justice of legislation will be put in question before judges. This is a radical departure from the AngloCanadian tradition. Even if $s .7$ is held to import only procedural fundamental justice, the effect will be to enshrine and expand the developing duty of fairness. The former result would be a legal revolution, the latter, a mere evolution. Even if the courts may initially restrict themselves to monitoring procedural fundamental justice, in the long term, as the constitution develops, the actual wording of $\mathrm{s} .7$ may permit the more adventuresome alternative. 